\title{
Microbial Desulfurization of Diesel 0 ils by Selected Bacterial Strains
}

\author{
S. Abbad-Andaloussi ${ }^{*}$, M. Warzywoda ${ }^{1}$ and F. Monot ${ }^{1}$ \\ 1 Institut français du pétrole, 1 et 4, avenue de Bois-Préau, 92852 Rueil-M almaison C edex - France \\ e-mail: abbad@univ-paris12.fr - michel.warzywoda@ifp.fr - frederic.monot@ifp.fr \\ * Present address:
}

Laboratoire de biologie des sols et des eaux, UM R-IRD-Paris XII, 61, avenue du G énéral-de-G aulle, 94010 Créteil - France

\begin{abstract}
Résumé - Désulfuration microbiologique de gazoles par des souches bactériennes sélectionnées En raison du durcissement progressif des normes sur la teneur en soufre des carburants automobiles, la désulfuration biologique est souvent envisagée comme une alternative possible aux procédés d'hydrodésulfuration (HDS) profonde utilisés dans l'industrie du raffinage. La première souche microbienne capable d'oxyder spécifiquement le soufre d'une molécule comme le dibenzothiophène (DBT) sans affecter son contenu carboné, Rhodococcus erythropolis IGTS8, a été isolée il y a plus de dix ans. La voie métabolique suivie (voie des $4 \mathrm{~S}$ ) a été élucidée et les gènes responsables caractérisés et séquencés. La présente étude vise à tirer profit de la biodiversité microbienne pour sélectionner, sur la base de critères importants du point de vue industriel, de nouvelles souches potentiellement intéressantes pour une désulfuration ultraprofonde des gazoles. Dans un premier temps, 15 souches pures capables d'utiliser le DBT comme seule source de soufre et de le convertir en 2-hydroxybiphényle (HBP) ont été isolées à partir de différents sols. Dans un second temps, 5 isolats appartenant au cluster Rhodococcus/Gordonia, ayant une bonne croissance et de fortes activités de désulfuration aussi bien en milieu aqueux qu'en milieu organique ont été sélectionnés. L'action des cellules non proliférantes obtenues à partir de ces souches vis-à-vis de différents types de gazole a été déterminée afin de mieux évaluer les potentialités de la biodésulfuration comme étape de finition d'une hydrodésulfuration profonde. En fait, malgré leur forte similitude taxonomique, les 5 souches ont des activités différentes sur les gazoles testés. Le taux de désulfuration dépend également du type de gazole, en particulier de sa teneur en soufre. Certains composés récalcitrants à l'HDS, comme le 4,6-diméthyl dibenzothiophène, peuvent être totalement désulfurés, mais les dibenzothiophènes fortement alkylés sont résistants à l'action des biocatalyseurs.
\end{abstract}

\footnotetext{
Abstract - Microbial Desulfurization of Diesel Oils by Selected Bacterial Strains - Because of increasingly stringent regulations concerning the sulfur content of motor fuels, sulfur removal by biocatalytic means is often considered as a potential alternative to conventional deep hydrodesulfurization processes used in the refinery industry. The first microbial strain able to selectively oxidize sulfur of molecules such as dibenzothiophene (DBT) without altering its carbon content, Rhodococcus erythropolis IGTS8, was isolated more than ten years ago. The metabolic pathway (4S pathway) was elucidated and the genes involved characterized and sequenced. The present study aimed at exploiting microbial diversity to select new strains potentially interesting for ultradeep desulfurization of diesel oils, taking into account industrially important criteria. In a first step, 15 pure strains able to use DBT as a sole sulfur source and to convert it to 2-hydroxybiphenyl (HBP) were obtained from different soils. In a second step, 5 isolates belonging to the Rhodococcus/Gordonia cluster and exhibiting
} 
good growth characteristics and high biodesulfurization activities in both aqueous and organic media were selected. The action of resting cells from these strains towards different types of diesel oils was also determined in order to better assess the potentiality of biodesulfurization, especially as a finishing step complementary to deep hydrodesulfurization (HDS). Actually, in spite of their taxonomic similarity, the 5 strains displayed different activities towards the diesels oil tested. Biodesulfurization yield was also dependent upon the diesel oil used, especially its sulfur content. Some HDS-recalcitrant compounds such as 4,6-dimethyl dibenzothiophene, could be completely removed, but highly-alkylated dibenzothiophenes were resistant to the action of the biocatalysts.

\section{IN TRO DUCTIO N}

The combustion of sulfur-containing fuels yields sulfur oxides (SOx) which are air pollutants. Environmental agencies are imposing more and more stringent regulations standards on the sulfur content of petroleum products such as gasoline and diesel oil. For example, the sulfur content in diesel oil will probably be less than 10 or $15 \mathrm{ppm}(\mathrm{w} / \mathrm{w})$ in United States and Europe by 2010. The sulfur content of crude oil ranges from 0.04 to $6 \%(\mathrm{w} / \mathrm{w})$ according to its origin. After distillation, dibenzothiophene (DBT) and alkylated dibenzothiophenes $\left(\mathrm{C}_{\mathrm{x}}\right.$-DBTs) are concentrated in the middle distillate fractions and they may represent up to $70 \%$ of the sulfur present in diesel oil. Conventional chemical hydrodesulfurization (HDS) processes used in the refinery industry cannot completely remove these heterocyclic organosulfur compounds and biodesulfurization (BDS) has been considered as an alternative to ultradeep HDS $[1,2]$.

Several aerobic bacterial strains able to selectively oxidize the sulfur atom of DBT without degrading its carbon skeleton have been isolated [2,3]. The final products of DBT conversion are 2-hydroxybiphenyl (HBP) and sulfite. This pathway, often named the $4 \mathrm{~S}$ pathway, has been elucidated using the first strain found able to use DBT as a sole sulfur source, Rhodococcus erythropolis IGTS8 [4, 5] (Fig. 1). The four genes involved have been isolated and sequenced [3,6]. The first two enzymes, DszC and DszA, are $\mathrm{FMNH}_{2}$-dependent monooxygenases catalysing the successive oxidations of DBT to DBT-sulfone and then to 2-hydroxybiphenyl-2'-sulfinic acid [7]. The $\mathrm{FMNH}_{2}$ required is supplied by DszD, a NADH-flavin mononucleotide oxidoreductase. Finally, a desulfinase (DszB) is responsible for the formation of HBP from HBP-sulfinate. The multienzymatic nature of the $4 \mathrm{~S}$ pathway and the requirement for cofactors make the use of pure enzymes inappropriate from a process point of view [8]. Most mesophilic strains possessing the $4 \mathrm{~S}$ pathway belong to the Rhodococcus genus and the $d s z$ genotype seems to be well preserved among them $[9,10]$.

The present study aimed at selecting new efficient strains, taking into account several properties which could be crucial for the implementation of a BDS process, such as activity and stability of resting cells in aqueous or organic media, activity on alkylated DBTs. The biodesulfurization activity of the selected strains on different types of diesel oils was also investigated and their action on the different structural classes of DBT derivatives determined.

\section{MATERIALS AND METHODS}

\subsection{Isolation of Strains}

Soil samples from different sites (coal storage, polluted soil) were used to isolate biodesulfurizing strains. A standard minimum synthetic sulfate-free (SMM) liquid culture medium containing $25 \mathrm{mg} \cdot \mathrm{l}^{-1}$ DBT as a sole sulfur source and a mixture of glucose, glycerol and sodium succinate as carbon sources was used for enrichment cultures [11]. After at least four successive transfers in liquid media, isolated colonies could be obtained by streaking on solid SMM medium. The purity of the strains obtained was checked on Tryptone Soy Agar and they were cultivated on a modified liquid SMM containing only glycerol and succinate as carbon sources (MSMM). In some cases, $10 \mathrm{mg} \cdot \mathrm{l}^{-1}$ dimethylsulfoxyde (DMSO) was used instead of DBT. Strains were identified according to their phenotypic characteristics and their 16S rDNA sequence [11].

\subsection{Conversion of DBT}

Cells previously cultivated on MSMM and washed with $0.1 \mathrm{M}$ potassium phosphate buffer $(\mathrm{pH}$ 7.0) were used as resting cells for conversion of DBT or diesel oil. The DBT conversion medium contained $2 \mathrm{~g} \cdot \mathrm{l}^{-1}$ cell dry weight in $0.1 \mathrm{M}$ phosphate buffer ( $\mathrm{pH} 7.0$ ) and $25 \mathrm{mg} \cdot \mathrm{l}^{-1} \mathrm{DBT}$. The cells used were frozen at $-80^{\circ} \mathrm{C}$ (freezing did not change the activity of cells). The reaction was carried out at $30^{\circ} \mathrm{C}$ and was followed for $24 \mathrm{~h}$. The reaction was stopped by addition of a known amount of acetonitrile. The activity of the cells was determined from the rate of DBT consumption or HBP formation during the first $2 \mathrm{~h}$. Two control experiments (one without cells, one without addition of DBT) were performed under the same conditions. In the case of conversions in the presence of an organic phase (hexadecane or diesel oil), the concentrations of sulfur compounds and their metabolites were measured in the organic phase. 
Dibenzothiophene (DBT)<smiles>c1ccc2c(c1)sc1ccccc12</smiles>

DBT-monooxygenase (DszC)

DszD

$\mathrm{NADH}, \mathrm{FMNH}_{2}, \mathrm{O}_{2}$<smiles>O=S1c2ccccc2-c2ccccc21</smiles>

DBT-monooxygenase (DszC)

DszD

$\mathrm{NADH}, \mathrm{FMNH}_{2}, \mathrm{O}_{2}$

DBT-sulfone<smiles>O=S1(=O)c2ccccc2-c2ccccc21</smiles>

DBT-sulfone monooxygenase (DszA)

DszD

$\mathrm{NADH}, \mathrm{FMNH}_{2}, \mathrm{O}_{2}$

2-hydroxybiphenyl

2'-sulfinate<smiles>O=S([O-])c1cccc(-c2ccccc2O)c1</smiles>

2-hydroxybiphenyl sulfinate desulfinase (DszB)

2-hydroxybiphenyl

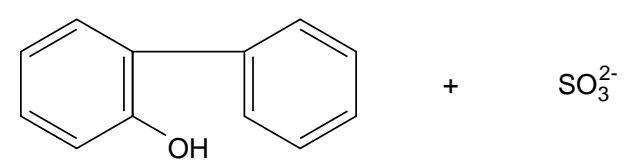

Figure 1

DBT desulfurization pathway by Rhodococcus IGTS8 (4S pathway). 


\subsection{Conversion of Diesel 0 ils}

Biodesulfurization of diesel oils was carried out in shaken Fernbach flasks containing $200 \mathrm{ml} 0.1 \mathrm{M}$ phosphate buffer $(\mathrm{pH} 7)$ and $40 \mathrm{ml}$ diesel oil (oil $/$ water ratio $=0.2$ ). The concentration of resting cells was $2 \mathrm{~g} \cdot \mathrm{l}^{-1}$ (dry weight). Incubation time and temperature were $96 \mathrm{~h}$ and $30^{\circ} \mathrm{C}$, respectively. Abiotic controls were performed in the same conditions without biocatalyst. The sulfur content and sulfur composition of diesel oil were determined using the organic phase. Desulfurization yields were calculated taking the sulfur content of the abiotic controls as the initial value. The characteristics of the different types of diesel oils used are indicated in Table 1.

TABLE 1

Main characteristics of the diesel oils used

\begin{tabular}{l|l|c|c}
\hline Diesel oil & \multicolumn{1}{|c|}{ Origin } & $\begin{array}{c}\text { Hydro- } \\
\text { desulfurization }\end{array}$ & $\begin{array}{c}\text { Sulfur content } \\
\left(\mathrm{mg} \cdot \mathrm{kg}^{-1}\right)\end{array}$ \\
\hline 3990 & $\mathrm{SR}^{\mathrm{a}}$ & No & $440^{*}$ \\
103 & $\mathrm{SR}$ & Moderate & 535 \\
104 & $\mathrm{SR}$ & Deep & 45 \\
101 & $\left(\mathrm{SR}+\mathrm{LCO}^{\mathrm{b}}\right)(0.5 / 0.5)$ & Moderate & 660 \\
$690 \mathrm{~A}$ & $(\mathrm{SR}+\mathrm{LCO})(0.5 / 0.5)$ & Deep & 29 \\
$5290 \mathrm{~B}$ & $(\mathrm{SR}+\mathrm{LCO})(0.5 / 0.5)$ & Deep & 185 \\
\hline
\end{tabular}

a: straight-run.

b: light cycle oil (gas-oil type fraction from catalytic cracking units).

*: original sulfur content: $1.5 \%$ (diluted to $440 \mathrm{mg} \cdot \mathrm{kg}^{-1}$ in hexadecane).

\subsection{Analyses}

DBT and its degradation products were quantified by reversed phase HPLC coupled to UV detection [11]. Samples of bioconversion supernatants were mixed with acetonitrile before injection. The metabolites of DBT and of 4,6dimethyl DBT were identified by GC/MS after extraction in dichloromethane. The total sulfur content of diesel oil was evaluated by X-ray fluorescence and the composition of the organo-sulfur compounds of diesel oil was determined by gas phase chromatography coupled to sulfur-specific chemiluminescence detection (SCD).

16S rDNA sequencing was carried out after DNA extraction and amplification by PCR using primers usually used for amplification of 16S rDNA of Procaryotes [12]. Sequencing was performed by ESGS (Evry, France) and sequences were compared using the BLAST 2 software (National Center for Biotechnology Information, NCBI).

\section{RESULTS}

\subsection{Selection and Properties of Efficient DBT-Desulfurizing Strains}

Fifteen pure strains able to use DBT as a sole sulfur source were isolated. DBT was converted to HBP in each case. The ability of these strains to maintain a DBT-desulfurizing activity after growth on dimethyl-sulfoxide (DMSO) was tested (Table 2). Sulfate, which is the usual sulfur source of bacteria, was not used since it is known to repress the expression of the $d s z$ genes [13]. Eight strains could be selected based on this criterion. A classical phenotypic analysis showed that they all belonged to the Rhodococcus genus.

The DBT-desulfurizing activity of the resting cells obtained from the different strains precultivated in identical conditions was measured in both aqueous and organic media (Table 3). The decrease of activity caused by the presence of

TABLE 2

Biodesulfurization activity after growth on DMSO as a sulfur source (+: production of 2-hydroxybiphenyl; -: no production of 2-hydroxybiphenyl)

\begin{tabular}{l|cccc|ccc|ccc|cc|cc|cc}
\hline No. sample & \multicolumn{4}{|c|}{ MK2 } & \multicolumn{3}{|c|}{ MK2-T3 } & \multicolumn{3}{c|}{ MK3 } & \multicolumn{3}{c|}{ MK5 } & \multicolumn{3}{c}{ MK7 } \\
\hline Strain & 3 & 4 & 5 & 8 & C1 & C2 & C3 & C2 & C3 & T & C1 & C2 & C1 & C2 & C3 \\
\hline Activity & + & + & + & + & - & - & - & - & - & - & + & - & + & + & + \\
\hline
\end{tabular}

TABLE 3

Biodesulfurization activity in aqueous and organic (90\% hexadecane) media (mg DBT consumed $\cdot \mathrm{h}^{-1} \cdot \mathrm{g}^{-1}$ cell dry weight)

\begin{tabular}{l|c|c|c|c|c|c|c|c}
\hline & MK2-3 & MK2-4 & MK2-5 & MK2-8 & MK5-C1 & MK7-C1 & MK7-C2 & MK7-C3 \\
\hline Aqueous medium & 3.9 & 2.8 & 3.2 & 2.2 & 2.2 & 3.9 & 1.9 & 2.8 \\
\hline Organic medium & 0.89 & 1.2 & 0.7 & 0.6 & 0.9 & 1.7 & 0 & 1.4 \\
\hline $\begin{array}{l}\text { Ratio of activity } \\
\text { (organic/aqueous) }\end{array}$ & 0.23 & 0.41 & 0.20 & 0.28 & 0.40 & 0.43 & 0 & 0.50 \\
\hline
\end{tabular}


hexadecane was determined to select the 5 strains that were the least sensitive to the presence of an organic solvent. The ratio of the activities in the 2 types of medium was taken into account rather than the value of activity itself. The selected strains were identified by $16 \mathrm{~S}$ rDNA sequencing as Rhodococcus erythropolis or Gordonia sp. strains (Table 4). The strain MK7-C1 showed the 16S rDNA highest similarity with $R$. erythropolis IGTS8 $(99.1 \%)$. The stability of the DBT-desulfurizing activity of the resting cells and their activity on 4,6-dimethyl DBT varied according to the strain used [11]. For instance, the resting cells from strain MK5-C1 were inactive on 4,6-dimethyl DBT whereas those from MK7-C1 were more active on this alkylated DBT than on DBT. These strains were deposited at the Collection nationale de cultures de microorganismes (CNCM, Institut Pasteur, France).

\subsection{Desulfurization Activity of the Selected Strains on Different Types of Diesel O il}

The desulfurization yields calculated from the total sulfur content of various types of diesel oil after $96 \mathrm{~h}$ incubation in the presence of resting cells from the selected strains are shown in Figure 2. The results obtained using strain MK5-C1 are not shown because the desulfurization yield was always around 0 .

The other strains exhibited a desulfurization activity on all types of diesel oil tested. Using strain MK7-C1 and diesel oil $690 \mathrm{~A}$, the total desulfurization yield was close to $50 \%$. However, the final desulfurization yield was highly dependent on the diesel oil used. The higher was the sulfur content, the lower was the desulfurization yield. The highest yields were obtained with the diesel oil having the lowest

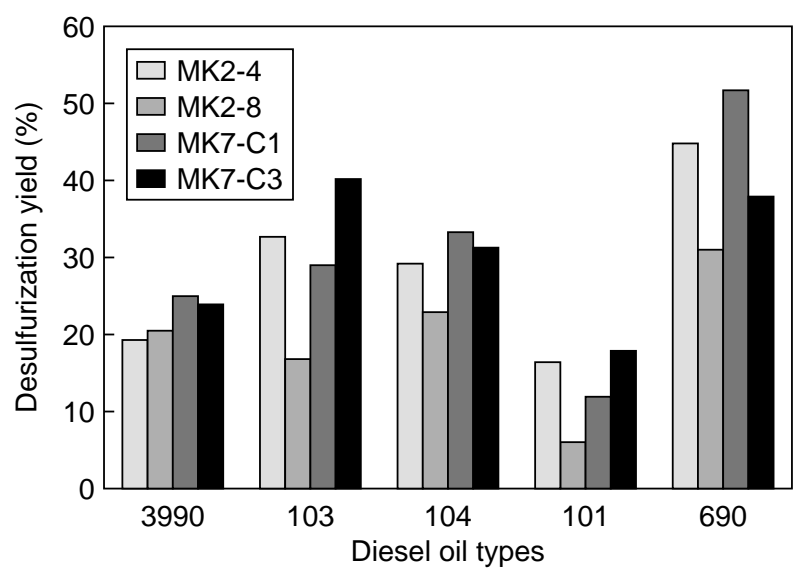

Figure 2

Action of the selected strains on the different diesel oils.

initial sulfur content (around $30 \mathrm{mg} \cdot \mathrm{kg}^{-1}$ ), although it was a mixture of straight-run middle distillate and LCO. Besides, it is noteworthy that the desulfurization activity was also dependent on the strain used. Apart from strain MK5-C1, the least active one was MK2-8. The other strains gave similar results.

\subsection{Modification of the Composition in 0 rgano-Sulfur Compounds of the Diesel Oils}

The detailed analysis of the sulfur components was carried out on some samples to better investigate the desulfurizing action of the biocatalysts tested, especially on alkylated dibenzothiophenes $\left(\mathrm{C}_{\mathrm{x}}\right.$-DBTs). Some of these compounds, i.e. $\mathrm{DBT}, \mathrm{C}_{1}$-DBT and $\mathrm{C}_{2}$-DBTs, could be identified.

TABLE 4

Identification of the 5 strains selected

\begin{tabular}{|c|c|c|c|}
\hline \multirow{2}{*}{$\begin{array}{l}\text { Strain } \\
\left(\mathrm{N}^{\circ} \mathrm{CNCM}\right)\end{array}$} & \multicolumn{3}{|c|}{ Identification by } \\
\hline & $\begin{array}{c}\text { Classical microbiological } \\
\text { analyses }\end{array}$ & $\begin{array}{l}\text { Cell wall and } \\
\text { total protein analysis }\end{array}$ & $\begin{array}{l}\text { 16S rDNA sequence } \\
\text { with highest similarity }\end{array}$ \\
\hline $\begin{array}{l}\text { MK2-4 } \\
(\mathrm{I}-2204)\end{array}$ & Rhodococcus equi & Rhodococcus erythropolis & $\begin{array}{c}\text { Rhodococcus sp. } \\
\text { or R. erythropolis }(100 \%)\end{array}$ \\
\hline $\begin{array}{l}\text { MK2-8 } \\
(\mathrm{I}-2205)\end{array}$ & Rhodococcus equi & Rhodococcus erythropolis & $\begin{array}{c}\text { Rhodococcus sp. } \\
\text { or R. erythropolis }(100 \%)\end{array}$ \\
\hline $\begin{array}{l}\text { MK5-C1 } \\
(\mathrm{I}-2206)\end{array}$ & Rhodococcus equi & Rhodococcus rhodnii/Gordonia & Gordonia sp. (97.0\%) \\
\hline $\begin{array}{l}\text { MK7-C1 } \\
(\mathrm{I}-2207)\end{array}$ & Rhodococcus sp. & Rhodococcus erythropolis & $\begin{array}{c}\text { Rhodococcus sp. } \\
\text { or R. erythropolis }(99.99 \%)\end{array}$ \\
\hline $\begin{array}{l}\text { MK7-C3 } \\
(\mathrm{I}-2208)\end{array}$ & Rhodococcus sp. & Rhodococcus erythropolis & $\begin{array}{c}\text { Rhodococcus sp. } \\
\text { or R. erythropolis ( } 99.99 \%)\end{array}$ \\
\hline
\end{tabular}


The middle distillate S3990 diluted in hexadecane was the sole fraction tested containing benzothiophenes (BTs). The action of MK2-4 and MK7-C1 which were the least active and the most active strains, respectively, is shown in Table 5. In addition to dibenzothiophenes, benzothiophenes were attacked by both biocatalysts. However, the desulfurization yields remained limited.

TABLE 5

Desulfurization yields $(\Delta \mathrm{S})$ of the families of organo-sulfur compounds after the action of different biocatalysts (diesel oil S3990)

\begin{tabular}{|c|c|c|c|}
\hline Sulfur compound & $\begin{array}{c}\text { Abiotic } \\
\text { Sulfur concentration } \\
\left(\mathrm{mg} \cdot \mathrm{kg}^{-1}\right)^{\mathrm{a}}\end{array}$ & $\begin{array}{c}\text { MK2-4 } \\
\Delta \mathrm{S}(\%)^{\mathrm{b}}\end{array}$ & $\begin{array}{c}\text { MK7-C1 } \\
\Delta \mathrm{S}(\%)^{\mathrm{b}}\end{array}$ \\
\hline $\mathrm{C}_{1}$ BTs & 4 & 36.6 & 50.0 \\
\hline $\mathrm{C}_{2}$ BTs & 12 & 38.9 & 42.4 \\
\hline $\mathrm{C}_{3}$ BTs & 30 & 43.6 & 48.3 \\
\hline $\mathrm{C}_{4} \mathrm{BTs}$ & 66 & 23.5 & 30.5 \\
\hline BTs (total) & 112 & 31.0 & 37.3 \\
\hline DBT & 8 & 18.8 & 25.9 \\
\hline Total C ${ }_{1}$ DBTs & 76 & 10.8 & 18.2 \\
\hline Total C $\mathrm{C}_{2}$ DBTs & 59 & 24.7 & 30.6 \\
\hline Total $C_{3}$ DBTs & 183 & 11.9 & 18.3 \\
\hline
\end{tabular}

a: sulfur concentration of each family of compounds. b: sulfur removal with respect to the abiotic control.

The desulfurization capacities of the 4 strains towards the different sulfur species of a moderately-hydrodesulfurized diesel oil (sample 103) were compared (Table 6 and Fig. 3). This diesel oil sample contained around $500 \mathrm{mg} \cdot \mathrm{kg}^{-1}$ sulfur. Sulfur constituents were only alkylated DBTs. Significant differences between strains could be observed, especially when considering the lower action of strain MK2-8 on 4,6-dimethyl DBT, 4-methyl-6-ethyl DBT and 2,4,6-methyl DBT. $\mathrm{C}_{2}$-DBTs were highly attacked by the biocacalysts. The most recalcitrant compounds were probably $\mathrm{C}_{\mathrm{x}}$-DBTs with an alkylation degree greater than 3 .

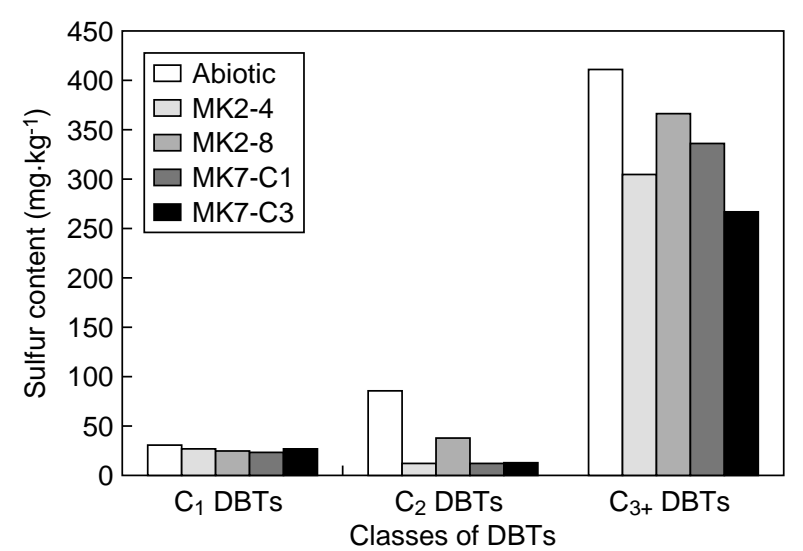

Figure 3

Alkylated dibenzothiophene content change after treatment of a moderately-hydrodesulfurized diesel oil (sample 103). $\mathrm{C}_{3}+$ DBTs $=\mathrm{C}_{3}$ and higher alkylated $\mathrm{C}_{\mathrm{x}}$-DBTs.

The action of strains MK2-4 and MK7-C1 towards diesel oil samples containing very low concentrations of sulfur was investigated using diesel oil 104 which was a deeplyhydrodesulfurized straight-run middle distillate and diesel oil 690A which contained 50\% deeply-hydrodesulfurized middle distillate and 50\% LCO. Results are presented in Figure 4 and Table 7 for sample 104 and in Figure 5 and Table 8 for sample 690A. The action of the 2 strains was similar in both cases. The desulfurization yield was higher with the mixture SR-LCO (690A). C $\mathrm{C}_{2}$-DBTs were completely removed. For instance, 4,6-dimethyl DBT, which was the predominant sulfur compound present after ultradeep hydrodesulfurization, was not detected after the action of the biocatalysts. Concerning diesel oil 690A, other compounds such as 4-methyl DBT, 4-ethyl DBT, 1,3- 3,4and 3,6-dimethyl DBT were also completely desulfurized. Some $\mathrm{C}_{3}$-DBTs (4-methyl-6-ethyl DBT and 2,4,6-methyl DBT) were removed to more than $90 \%$. However, the activity of the biocatalysts was lower when the degree of

TABLE 6

Removal $(\Delta S)$ of the predominant sulfur compounds of a moderately-hydrodesulfurized diesel oil (sample 103)

\begin{tabular}{l|c|c|c|c|c}
\hline \multirow{2}{*}{ Sulfur compound } & \multirow{2}{*}{$\begin{array}{c}\text { Initial sulfur } \\
\text { content } \\
\left(\mathrm{mg}^{*} \cdot \mathrm{kg}^{-1}\right)\end{array}$} & $\begin{array}{c}\text { MK2-4 } \\
(\Delta \mathrm{S})\end{array}$ & $\begin{array}{c}\text { MK2-8 } \\
(\Delta \mathrm{S})\end{array}$ & $\begin{array}{c}\text { MK7-C1 } \\
(\Delta \mathrm{S})\end{array}$ & $\begin{array}{c}\text { MK7-C3 } \\
(\Delta \mathrm{S})\end{array}$ \\
\cline { 3 - 6 } & 55.4 & 97 & 66 & 97 & 97 \\
4,6-Me DBT & 35.6 & 64 & 22 & 66 & 78 \\
4-Me-6-Et DBT & 35.5 & 87 & 28 & 82 & 100 \\
2,4,6-Me DBT & 27.5 & 86 & 33 & 85 & 90 \\
C3 DBT (unknown 1) & 35.8 & 55 & 26 & 53 & 65 \\
C3 DBT (unknown 2) & 35.5 \\
\hline
\end{tabular}




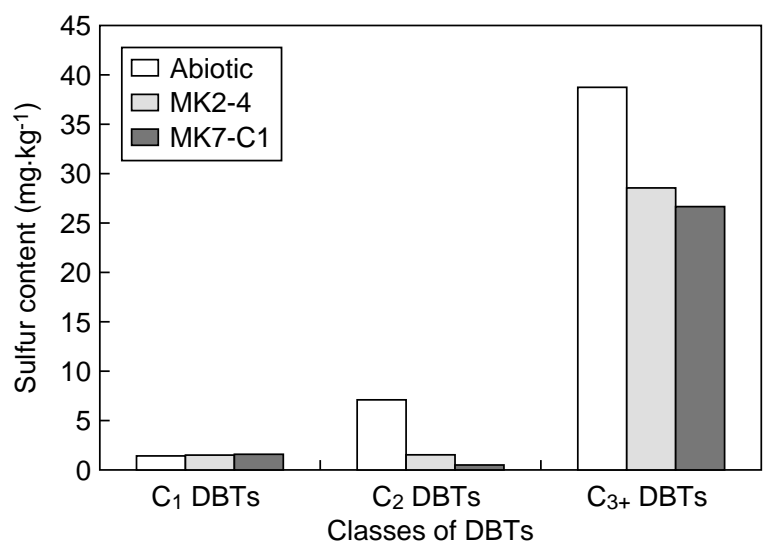

Figure 4

Alkylated dibenzothiophene content change after treatment of a deeply-hydrodesulfurized straight-run diesel oil (sample 104). $\mathrm{C}_{3}+$ DBTs $=\mathrm{C}_{3}$ and higher alkylated $\mathrm{C}_{\mathrm{x}}$-DBTs.

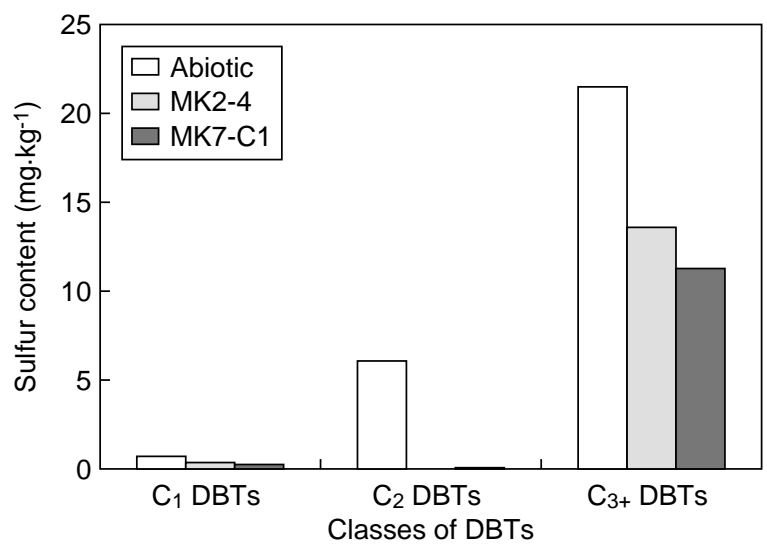

Figure 5

Alkylated dibenzothiophenes content change after treatment of a mixture of deeply-hydrodesulfurized straight-run and LCO diesel oils (sample 690A). $\mathrm{C}_{3}+$ DBTs $=\mathrm{C}_{3}$ and higher alkylated $\mathrm{C}_{\mathrm{x}}$-DBTs. alkylation of DBT became higher than 3. It is also worth mentioning that strain MK7-C1 was more efficient than strain MK2-4.

TABLE 7

Removal $(\Delta \mathrm{S})$ of the predominant sulfur compounds of a deeply-hydrodesulfurized straight-run diesel oil (sample 104)

\begin{tabular}{|c|c|c|c|}
\hline \multirow[b]{2}{*}{ Sulfur compound } & \multirow{2}{*}{$\begin{array}{l}\text { Initial sulfur } \\
\text { content } \\
\left(\mathrm{mg} \cdot \mathrm{kg}^{-1}\right)\end{array}$} & \multicolumn{2}{|c|}{ Sulfur removal $(\Delta \mathrm{S})$ by strain $(\%)$} \\
\hline & & $\begin{array}{c}\text { MK2-4 } \\
(\Delta \mathrm{S})\end{array}$ & $\begin{array}{c}\text { MK7-C1 } \\
(\Delta S)\end{array}$ \\
\hline 4,6-Me DBT & 6.3 & 92 & 100 \\
\hline 4-Me-6-Et DBT & 4.6 & 86 & 89 \\
\hline 2,4,6-Me DBT & 2.1 & 65 & 83 \\
\hline C3 DBT (unknown 1) & 3.6 & 92 & 96 \\
\hline C3 DBT (unknown 2) & 3.5 & 39 & 49 \\
\hline
\end{tabular}

TABLE 8

Removal $(\Delta \mathrm{S})$ of the predominant sulfur compounds of a mixture of deeply-hydrodesulfurized straight-run and LCO diesel oils (sample 690A)

\begin{tabular}{l|c|c|c}
\hline \multirow{2}{*}{ Sulfur compound } & \multirow{2}{*}{$\begin{array}{c}\text { Initial sulfur } \\
\text { content } \\
\left(\mathrm{mg}^{\mathrm{k}} \mathrm{kg}^{-1}\right)\end{array}$} & $\begin{array}{c}\text { MK2-4 } \\
(\Delta \mathrm{S})\end{array}$ & $\begin{array}{c}\text { MK7-C1 } \\
(\Delta \mathrm{S})\end{array}$ \\
\cline { 3 - 4 } & 4.9 & 100 & 99 \\
\hline 4,6-Me DBT & 2.5 & 83 & 90 \\
4-Me-6-Et DBT & 2.6 & 91 & 95 \\
2,4,6-Me DBT & 1.8 & 92 & 93 \\
C3 DBT (unknown 1) & 2.2 & 39 & 48 \\
C3 DBT (unknown 2) & &
\end{tabular}

\subsection{Kinetics of Diesel O il Desulfurization}

The time-course of desulfurization of diesel oil was studied using a mixture of deeply-hydrodesulfurized straight-run diesel oil and LCO and resting cells from strain MK7-C1. The diesel oil sample contained only $\mathrm{C}_{\mathrm{x}}$-DBTs as sulfur compounds. $\mathrm{C}_{3}$-DBTs could be separated from more alkylated DBTs by GC. The results are presented on Figure 6. The total sulfur removal after $48 \mathrm{~h}$ was $76 \%$. Sulfur from $\mathrm{C}_{1^{-}}$and $\mathrm{C}_{2}$-DBTs was completely removed after $10 \mathrm{~h}$ and $70 \%$ of the $\mathrm{C}_{3}$-DBTs could be desulfurized. $\mathrm{C}_{\mathrm{x}}$ DBTs with a higher alkylation degree were not attacked. The initial sulfur removal rate was equal to $1.86 \mathrm{mg} \cdot \mathrm{g}^{-1} \cdot \mathrm{h}^{-1}$.

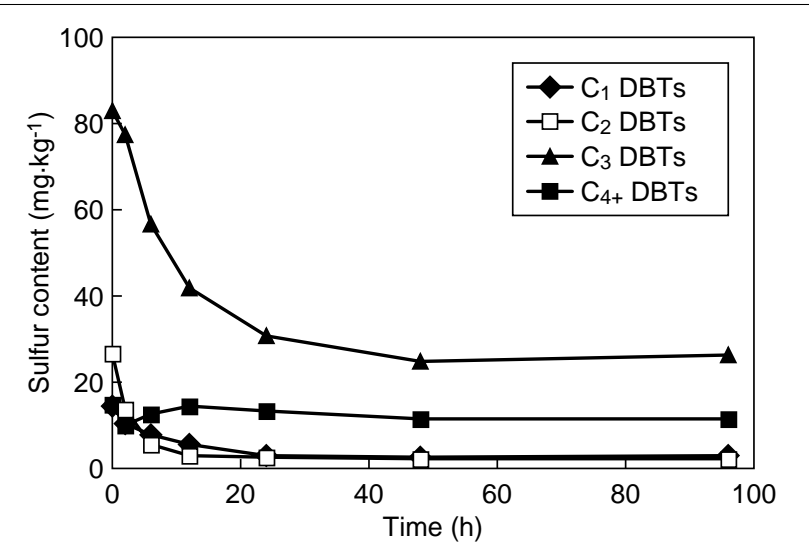

Figure 6

Time-course of the concentrations of alkyl-DBTs of a mixture of deeply-hydrodesulfurized and LCO diesel oils (sample 5290B) by cells of strain MK7-C1. Initial sulfur content: $185 \mathrm{mg} \cdot \mathrm{kg}^{-1}$; cell concentration: $2 \mathrm{~g} \cdot \mathrm{l}^{-1}$; oil/water ratio: 0.23 ; temperature: $30^{\circ} \mathrm{C} . \mathrm{C}_{4}+\mathrm{DBTs}=\mathrm{C}_{4}$ and higher alkylated $\mathrm{C}_{\mathrm{x}}$-DBTs. 


\section{CONCLUSIONS}

Some of the strains selected in the present work were able to efficiently desulfurize DBT and some alkylated DBTs. They all belonged to the Rhodococcus genus like many other desulfurizing strains $[9,10]$. Despite their phylogenetic similarity, they exhibited different properties. It was shown that these discrepancies could not be ascribed to a difference in the sequence of the $d s z$ genes and thereby to the structure of the desulfurization enzymes [11]. The phenomena involved in biodesulfurization are complex. In addition to the intracellular desulfurization itself, they include transport of hydrophobic substrates (DBTs) and inhibitory products (biphenyls) and supply of cofactors such as NADH [2]. These phenomena remain poorly documented. From an applied point of view, some other aspects which are crucial for the implementation of a biodesulfurization process in a refining scheme, e.g. stability of resting cells, activity in the presence of high levels of organic phase, have been studied here using several strains. These criteria were included in the selection of the best strains.

The present study also shows that some strains are highly active on diesel oil. However, the biodesulfurization activity and extent were dependent on both the type of diesel oil and on the strain used. For instance, strain MK5-C1, which is quite stable and active on DBT in organic media, was not able to desulfurize hydrodesulfurized middle distillate. This result can be explained by the narrow substrate specificity of this biocatalyst which could not oxidize 4,6-dimethyl DBT, a major constituent of hydrodesulfurized diesel oils. Previous studies devoted to the biodesulfurization of petroleum distillates did not present any comparison between strains and types of diesel oil [14-16]. We observed that biodesulfurization was more efficient on diesel oils with a low sulfur content and that biocatalysts were also active on LCO. This result suggests that inhibitory or toxic effects by certain sulfur compounds may occur. A maximum biodesulfurization yield of $76 \%$ was obtained and it was possible to decrease the sulfur content of a previously deeplyhydrodesulfurized diesel oil down to $14 \mathrm{mg} \cdot \mathrm{kg}^{-1}$. In addition, the sulfur removal rate was high. Furthermore, some HDSrecalcitrant compounds such as 4,6-dimethyl DBT could be totally desulfurized. The desulfurization kinetics were affected by the number and/or lengths of alkyl groups attached to the ring structure of DBT. From a technical point of view, these results show that biodesulfurization could be quite suitable as a finishing step complementary to deep HDS because of its high selectivity. However, the action of the biocatalysts on the highly-alkylated DBTs remained low and these compounds would also have to be removed to decrease the sulfur content of diesel oil to levels as low as $10 \mathrm{mg} \cdot \mathrm{kg}^{-1}$. That means that it would be necessary now to find biocatalysts that are active towards these target compounds. New strategies involving selection of new strains either by classical microbiological techniques or by directed molecular evolution need to be combined to construct biocatalysts possessing a larger substrate specificity [17].

\section{ACKN O W LEDG EMEN TS}

We thank T. Chapus and F. Morel for providing the diesel oil samples, A. Bré and S. Carbonneaux for GC/SCD analyses and F. Baco for X-ray fluorescence analyses.

\section{REFEREN CES}

1 McFarland, B.L. (1999) Biodesulfurization. Curr. Op. Microbiol., 2, 257-264.

2 Monticello, D.J. (2000) Biodesulfurization and the Upgrading of Petroleum Distillates. Curr. Op. Biotechnol., 11, 540-546.

3 Ohshiro, T. and Izumi, Y. (1999) Microbial Desulfurization of Organic Sulfur Compounds in Petroleum. Biosci. Biotechnol. Biochem., 63, 1-9.

4 Kayser, K.J., Bielaga-Jones, B.A., Jackowski, K., Odusan, O. and Kilbane, J.J. (1993) Utilization of Organosulphur Compounds by Axenic and Mixed Cultures of Rhodococcus rhodochrous IGTS8. J. Gen. Microbiol., 139, 3123-3129.

5 Oldfield, C., Pogrebinsky, O., Simmonds, J., Olson, E.S. and Kulpa, C.F. (1997) Elucidation of the Metabolic Pathway for Dibenzothiophene Desulphurization by Rhodococcus sp. Strain IGTS8 (ATCC 53968). Microbiology, 143, 2961-2973.

6 Denome, S.A., Oldfield, C., Nash, L.J. and Young, K.D. (1994) Characterization of the Desulfurization Genes from Rhodococcus sp. strain IGTS8. J. Bacteriol., 176, 6707-6716.

7 Gray, K.A., Pogrebinsky, O.S., Mrachko, G.T., Xi, L., Monticello, D.J. and Squires, C.H. (1996) Molecular Mechanisms of Biocatalytic Desulfurization of Fossil Fuels. Nature Biotechnol., 14, 1705-1709.

8 Monticello, D.J. (1998) Riding the Fossil Fuel Biodesulfurization wave. Chemtech, 28, 38-45.

9 Denis-Larose, C., Labbé, D., Bergeron, H., Jones, A.M., Greer, C.W., Al-Hawari, J., Grossman, M.J., Sankey, B.M. and Lau, P.C.K. (1997) Conservation of Plasmid-Encoded Dibenzothiophene Desulfurization Genes in Several Rhodococci. Appl. Environ. Microbiol., 63, 2915-2919.

10 Duarte, G.F., Rosado, A.S., Seldin, L., de Araujo, W. and van Elsas, J.D. (2001) Analysis of Bacterial Community Structure in Sulfurous-Oil-Containing Soils and Detection of Species Carrying Dibenzothiophene Desulfurization ( $d s z$ ) genes. Appl. Environ. Microbiol., 67, 1052-1062.

11 Abbad-Andaloussi, S., Lagnel, C., Warzywoda, M. and Monot, F. (2003) Multi-Criteria Comparison of Resting Cell Activities of Bacterial Strains Selected for Biodesulfurization of Petroleum Compounds. Enzyme Microb. Technol., 32, 446-454.

12 Weisburg, W.G., Barns, S.M., Pelletier, D.A. and Lane, D.J. (1991) 16S Ribosomal DNA Amplification for Phylogenetic Study. J. Bacteriol., 173, 697-703.

13 Li, M.Z., Squires, C.H., Monticello, D.J. and Childs, J.D. (1996) Genetic Analysis of the $d s z$. Promoter and Associated Regulatory Regions of Rhodococcus erythropolis IGTS8. J. Bacteriol., 178, 6409-6418.

14 Folsom, B.R., Schieche, D.R., Digrazia, P.M., Werner, J. and Palmer, S. (1999) Microbial Desulfurization of Alkylated Dibenzothiophenes from a Hydrodesulfurized Middle 
Distillate by Rhodococcus erythropolis I-19. Appl. Environ. Microbiol., 65, 4967-4972.

15 Grossman, M.J., Lee, M.K., Prince, R.C., Minak-Bernero, V., George, G.N. and Pickering, I.J. (2001) Deep Desulfurization of Extensively Hydrodesulfurized Middle Distillate Oil by Rhodococcus sp. Strain ECRD-1. Appl. Environ. Microbiol., 67, 1949-1952.

16 Kobayashi, M., Horiuchi, K., Yoshikawa, O., Hirasawa, K., Ishii, Y., Fujino, K., Sugiyama, H. and Maruhashi, K. (2001) Kinetic Analysis of Microbial Desulfurization of Model and
Light Gas Oils Containing Multiple Alkyl Dibenzothiophenes. Biosci. Biotechnol. Biochem., 65, 298-304.

17 Coco, W.M., Levinson, W.E., Crist, M.J., Hektor, H.J., Darzins, A., Pienkos, P.T., Squires, C.H. and Monticello, D.J. (2001) DNA Shuffling Method for Generating Highly Recombined Genes and Evolved Enzymes. Nature Biotechnol., 19, 354-359.

Final manuscript received in February 2003 